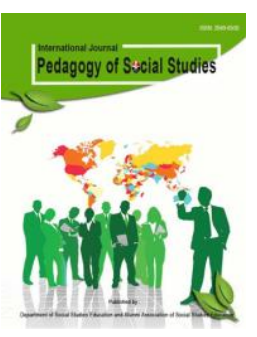

\title{
Optimization of The Role of FKUB And Kesbangpol Role (Nation and Political Unity) in Handling The Radical Movement of Terrorism in Tasikmalaya District
}

\author{
Rahmat $^{1}$, Prayoga Bestari ${ }^{2}$, Encep Syarief Nurdin ${ }^{3}$, Sri Wahyuni Tanshzil ${ }^{4}$ \\ ${ }^{1,2,4}$ Civic Education Department, Universitas Pendidikan Indonesia, Bandung, Indonesia \\ ${ }^{3}$ General Education Department, Universitas Pendidikan Indonesia, Bandung, Indonesia
}

\begin{abstract}
This study illustrates the synergy between the Forum for Religious Harmony (FKUB) with the National Unity and Politics (Kesbangpol) in dealing with the radical terrorism movement in Tasikmalaya Regency. Some efforts to handle religious conflicts that lead to radicalism movement include mapping conflict-prone areas, the formation of the Regional Intelligence Community (Kominda) and the Integrated Team for Handling Social Conflicts by the National Unity and Politics and the establishment of the Rukun Living Movement Task Force (SGHR) at the sub-district level by FKUB as a collaborative strategy step handling religious conflicts in Tasikmalaya Regency. The purpose of this study is to determine the role of FKUB as well as the synergy established between local governments, terrorism management institutions and the community in efforts to tackle radical terrorism. The method used in this study is a qualitative approach that emphasizes data collection through interviews, observations, documentation and focused discussions (Focus Group Discussion).
\end{abstract}

Keywords : Forum for Religious Harmony, National Unity and Politics, Addressing the Radical Movement of Terrorism, Tasikmalaya Regency

Correspondence.rahmat@upi.edu, yogabestari@upi.edu, encep.sn@upi.edu, sriwahyunitanshzil@upi.edu Article History. Received January 2020, Received in revised April 2020, Accepted June 2020 O2020. International Journal Pedagogy of Social Studies. Department of Social Studies

\section{A. INTRODUCTION}

Indonesia is one of the most multicultural countries in the world. Ethnic, cultural, and also religious heterogeneity are valuable social assets and assets for Indonesia. However, like the two sides of a coin, diversity has the potential to cause friction and conflict that threatens the integrity of the country. Not infrequently this has led to a variety of radical thoughts, especially those in the name of religion, which in the end were increasingly seen as scary when resulting in acts of terror that occurred in several cities in Indonesia. Various actions carried out by these terrorists have claimed many victims, both physical and psychological victims. Though religion teaches peace and safety that must be implemented by adherents (Nurjannah, 2013, p.179).

Indeed religion is a fundamental element in life that is a basic human right for every human being, therefore religious freedom must be respected and guaranteed by the state. Related to this, in Indonesia, every citizen is given the freedom to follow a religion of their choice. However, seeing so many conflicts in the name of religion, tolerance among religious believers must be the focus of government attention. Various efforts and policies must be carried out by the government to organize relations between religious communities in order to create stable and dynamic peace and harmony.

These efforts need to be intensively carried out, especially in areas that have 
been wary of becoming areas prone to terrorism such as West Java. West Java was once marked by the BNPT (National Counterterrorism Agency) as an area prone to being infiltrated by terrorists (Wijaya, 2013). As the province with the largest population in Indonesia, terrorist acts carried out in West Java will certainly have implications for Indonesia's national security. Moreover, aspects of terrorism are preceded by doctrination which can weaken one's ideology and national identity and end up being a threat to national security (Suryono, 2008).

One of the areas in the spotlight related to radicalism, terrorism and religious intolerance is Tasikmalaya. Famous as a base for DI (Darul Islam) and Masyumi in the past, Tasikmalaya is an area in West Java that has recently become popular because of the presence of radical Islamic organizations. Various terrorist events are nothing but a result of a series of events from the past. Although it has been crushed but this movement has metamorphosed into various forms of movement and new factions accompanied by new names and figures (Sofyan \& Marjani, 2016). The metamorphosis of the radical movement must continue to watch out because it can divide unity.

It must be realized that efforts to maintain and preserve unity and integrity need to be carried out. Recognizing this important meaning, one of the government's efforts to continue to enhance national unity is to form a National Unity and Politics Agency. The government also established the Forum for Religious Harmony (FKUB) in order to realize religious harmony, especially in the Tasikmalaya district.

It must be understood that in dealing with various issues, especially those related to terrorism, each agency cannot operate on its own. Optimal synergy and cooperation is needed so that the handling of terrorism in Tasikmalaya district can run effectively. On that basis the authors felt the need to conduct research with the aim of: (1) knowing the potential of religious conflict-prone areas in Tasikmalaya, and (2) examining the synergy of the role of FKUB and Kesbangpol in tackling radical terrorism movements in Tasikmalaya Regency.

\section{B. METHOD}

This study uses qualitative research methods that emphasize understanding of the problems in social life based on reality, complex and detailed conditions. (Anggito, 2018) Qualitative research is a scientific way to obtain data, facts and information with specific purposes and uses (Sugiono, 2010). The type of data collection used is through interviews, observation, documentation and focused discussion (Focus Group Discussion).

Information was selected by purposive sampling, which consisted of elements of Kesbangpol, Forum for Religious Harmony (FKUB) and the community. The Focus Group Discussion (FGD) technique with Kesbangpol and FKUB was carried out as primary data information and to bring up information about the desires, needs, perspectives and desired experiences and as a party involved in implementing the policy of combating radical terrorism in Tasikmalaya District.

The information obtained from the public is through interview techniques conducted face-to-face with an issue or theme raised in accordance with research and as a process of proving information or information obtained from BNPT data related to regions indicated by the spread of radical terrorism movements in Tasikmalaya Regency.

\section{RESULTS AND DISCUSSION}

\section{Radicalism and Terrorism}

Radicalism is interpreted as an understanding that wants rapid changes that are carried out by means of violence. Whereas in terms of terminology, radicalism comes from the word radix which means root (tree). The meaning of the word, can be expanded again, means a strong grip, belief, creator of peace and peace and other 
meanings. Radicalism itself has a root meaning, a lower root, which can also be interpreted as a whole, totality, and very hard in demanding change (Hemay, 2013).

Radicalism is quite closely related to terrorism, because terrorism itself is one of the methods used by individuals with radical ideas. It can also be said that radicalism is the embryo of terrorism. If the act of terrorism is a physical confrontation with a concrete negative impact in the form of damage to assets and threats to life, then it is different from radicalism. Radicalism triggers ideological confrontations that are not physical in nature so that their spread is difficult to trace.

Basically, a person does not immediately become radical, because to be radical certainly requires a process. According to Ramakrishna, the process is called radicalization, which means the process by which an individual changes from passivity or activism to become more militant, or extremist (Ramakrisna, 2009).

Meanwhile, according to Ezzat, terrorism has the basic word terror, which comes from the Latin word "terre", meaning to frighten. Generally, the word "terror" is used to describe the type of government, and the word 'terrorism' is used to describe terror specifically acts to regulate, suppress or conquer (Golose, 2014).

\section{Classification of Terrorism}

There are several categories of motivation that are commonly used as reasons for terrorism by a particular movement, including (US Army TRADOC, 2007):

1. Separatism. Motivation of the movement to gain group existence through recognition of independence, political autonomy, sovereignty, or religious freedom.

2. Ethnocentrism. Motivation based on the beliefs, and special social characteristics that tighten the group so that there is a classification of degrees of a race. This classification makes people or groups who have a race over arbitrarily with a lower racial group. The aim is to show power and strength (show of power) in order to recognize that the perpetrators enter the superior race (supreme race).

3. Nationalism. This motivation is loyalty and loyalty to a particular country or national understanding. This understanding cannot be separated from the cultural unity of the group, so that it intends to form a new government or be separated from a sovereignty to join a government that has the same national view or understanding.

4. Revolutionary. This motivation is a dedication to make changes or overthrow the government with new politics and social structures. This movement is synonymous with idealism and communism politics.

\section{Institutions dealing with the issue of Terrorism (in Tasikmalaya)}

In connection with the latent danger of terrorism, the government forms bodies to deal with it

1. Religious Harmony Forum (FKUB)

2. The National Unity, Politics and Community Protection Agency (Kesbangpolinmas) Tasikmalaya

3. Terrorism Countermeasure Communication Forum / FKPT (as BNPT Branch in Tasikmalaya Region),

The entire body coordinates intensively in terms of prevention and even eradication of terrorism, to the efforts to deradicalize the perpetrators so as not to return as terrorists (Putra, 2018). Synergy between these bodies, namely FKUB and Kesbangpol, which will be the subject of study in this study.

Radicalism and terrorism need to be watched by all parties, because conflicts that arise from social interaction, values in the form of identity or religion and religious pluralism can trigger conflict of ideas that lead to violent conflicts. It is undeniable that the existence of fanaticism from each of the different religions by believing that the truth is upon him can be a factor in the emergence of radical thoughts that lead to acts of terrorism. So based on research that has been done, there are several regional networks in Tasikmalaya District that are indicated as 
conflict-prone areas and are motivated by religious factors.

\section{Potential Areas of Religious Conflict Prone}

There are several facts that the people of Tasikmalaya Regency are still vulnerable to religious social-based radicalism. One of the parameters of vulnerability is seen from the level of community resistance to radical actions that are still not strong. Based on research released by the Setara Institute 2016 presented by Dr. KH. Utawijaya Kusumah, MM. (in the FGD on Terrorism Radicalism in Tasimalaya, August 21, 2019) which said that the scale of radicalism and intolerance in West Java showed a figure of $47.60 \%$ of the total points indicated as a center for the spread of terrorism.

Tasikmalaya is one of 10 (ten) regions which tend to have a high radical attitude in Indonesia besides Bogor, Bekasi, Kuningan, Aceh, Tangerang, Depok, Bandung, Sukabumi, Mataram and Serang. Thus the number of cases of radicalism that occurred in West Java, most of the spread came from the Tasikmalaya area (Utawijaya, 2019).

Some areas in Tasikmalaya Regency that have the potential to be prone to religious conflicts as strengthened by the existence of several studies that there are 43 cases of violations of religious freedom and intolerance; 76 cases of violation of freedom of religion and belief; and 35 cases of violations of religious life and belief. These areas include the following (Iwan, 2018).

1. Tenjowaringin Village, Kec. Salawu

2. Kutawaringin Village, Kec.Salawu

3. Kersamaju Village, Kec. Cigalontang

4. Tanjungkarang Village, Kec. Cigalontang

5. Sirnagalih Village, Kec. Sukaratu

6. Cariwuh Village, Singaparna District

7. Cibatu Village, Karangnunggal District

8. Cipakat Village, Kec Kecarna

9. Sukapura Village, Sukaraja District

10. Cigunung Village, Parungponteng Kec

11. Cipanas Village, Cipatujah District

12. Cikawung Ading Village, Cipatujah District

13. Pakemitan Village, Kec Ciawi

14. Kebonkapala Village, Kec. Buildreja
15. Cibuntiris Village, Kec. Bojong Gambir

16. Kreteg Village, Kec. Pagerageung

17. The Great Mosque of Tasikmalaya Regency

These areas are based on several religious conflict incidents, including conflicts between the Ahmadiyya Congregation and the Tasikmalaya Islamic Community Forum (FUI) regarding the disbanding of Ahmadiyah on April 18, 2008 and sealing assets belonging to the Ahmadiyah congregation on Jalan Cicariang Number 288, Kersamenak Village, Kawalu District, The City of Tasikmalaya by the Tasikmalaya Community Trust Flow Monitoring Board (Bakorpakem) Team on December 9, 2010 (Dielantik, 2013).

\section{Synergy of the Role of FKUB and Kesbangpol in Handling Radical Terrorism}

Kesbangpol improves intelligence functions to anticipate radicalism movements as well as early detection of the possibility of terrorist networks in Tasikmalaya Regency by forming Regional Intelligence Communities (Kominda) and the Integrated Team for Handling Social Conflict as a step in conflict management strategies based on Indonesian Minister of Domestic Affairs Regulation No. 42 of 2015 concerning Implementation of the Coordination of Social Conflict Management

The synergy between the Kesbangpol ranks and FKUB ranks in dealing with social problems related to terrorism has actually been well implemented. This was seen from the coordination meeting between FKUB management and the Kesbangpol that aimed to establish friendship and the formation of an integrated team as the Tasikmalaya Regent Decree on the Establishment of a Social Conflict Management Team in Tasikmalaya District.

FKUB as a mandatory organization that carries out PBM Number 8/9 of 2006 the Minister of Home Affairs and the Minister of Religion, carries out his tasks in conflict resolution efforts which subsequently forms 
the Tasikmalaya District Peace Movement Task Force (SGHR) at the sub-district level as a collaboration to direct early detection of symptoms of social vulnerability that lead to conflicts with religious social nuances.

The briefing was given as an effort by the Kesbangpol in conducting prevention in synergy with FKUB as a strategic partner in the implementation of prevention and handling programs on religious harmony that were implemented through several activities, including:

1. Increasing Tolerance in Efforts to Increase Nationality Insights and National Resilience;

2. Provision of khalaqah facilities and various other religious forums; and

3. Alien Control (Simpora).

Other strategies stipulated in the form of post-conflict recovery include reconciliation, rehabilitation and reconstruction which are implemented in the form of guidance on the Harmony and Religious Awareness Trilogy; and guidance on losses due to conflict. The synergy is woven into the same vision, namely the creation of a harmonious life in religion by promoting tolerance among religious people based on the Pancasila and the 1945 Constitution

\section{CONCLUSION}

Tasikmalaya Regency is one of the regencies in West Java Province that is very strategic in spreading Islamic teachings. Reflected from the image of Tasikmalaya, which until now is known as a city of santri and religious, because of the many pesantren that can spread Islamic teachings and become one of the objects to counter the development of radicalism. But if the government does not pay close attention to this, it can become a hotbed and network for the development of radical terrorism understandings.

The potential for religious conflict in Tasikmalaya Regency is still large, considering that historically there was a conflict between Muslims and Christians in Cikawungading Village, Cipatujah District regarding the burning of the church, the disbanding of Ahmadiyah and the attack and destruction of the Al-Idrisiyyah Islamic
Boarding School in Pagendingan, Cisayong District. This vulnerability was strengthened by data that showed $47.60 \%$ of the total regional points indicated as the center of the spread of terrorism and areas prone to religious conflict, one of which was found in Tasikmalaya.

The synergy between Kesbangpol and FKUB in preventing, detecting, counteracting and mitigating religious conflicts and terrorism movements is good enough. Evidenced by the existence of a strategy that promotes increased tolerance in an effort to increase national insight and national resilience, the provision of khalaqah facilities and various other religious forums, early detection of the spread of terrorist movements with a mapping strategy of conflict prone areas / regions, and the presence of Foreigners' Monitoring (Simpora). Thus in the collaborative effort carried out by religious leaders and government officials shows harmony and harmony between components related to strategic steps in handling religious conflict and acts of terrorism that can cause unrest in the Tasikmalaya people.and the special food of blood; and (5) Adding photographic features that represent the Indonesian traditional system.

\section{E. ACKNOWLEDGEMENT}

Our gratitude goes to the Indonesian University of Education and its research institutions which have facilitated us to be able to complete this research as well as all the components that have provided both moral and material encouragement

\section{REFERENCES}

Anggito, A \& Setiawan, J. (2018). Metodologi Penelitian Kuantitatif. Sukabumi: CV Jejak. hlm.9

Djelantik, S. dkk. (2013). Terorisme dan Kekerasan Berlatar Belakang Agama di Jawa Barat. Universitas Katolik Parahyangan: Bandung

Hemay, Idris dkk. (2013). Modul Pencegahan Terorisme di Daerah, Badan Nasional Pencegahan Terorisme (BNPT).

Iwan. (2018). Focus Group Discussion (Diskusi Kelompok Terfokus) 
sebagai Metode Pengumpulan Data Kualitatif. Bandung

Nurjannah. (2013). Faktor Pemicu Munculnya Radikalisme Islam Atas Nama Dakwah. Jurnal Dakwah, Vol.14 (2), hlm 179.

Petrus Reinhard Golose. (2014). Deradikalisasi Terorisme, Yayasan Pengembangan Kajian Ilmu Kepolisian,Jakarta, (selanjutnya disingkat Petrus Reinhard Golose II) hlm 3

Putra, I made dan I gusti agung. (2018). Sinergitas Kebijakan dan Strategi Pencegahan Tindak Pidana Terorisme di Provinsi Bali. Vyavahara Duta Universitas Udayana, Volume XIII, No.1.

Ramakrisna, Kumar. (2009). Radical Pathways: Understanding Muslim Radicalization in Indonesia, Preager Security Internasional: London

Sugiono, (2010). Metode Penelitian Kualitatif, $\quad$ Kuantitatif, $\quad R \& D$. Bandung: Alfabeta, hlm.52.
Suryono, H. (2008). "Konfigurasi Identitas Nasional, Nasionalisme dalam Era Globalisasi suatu Harapan dan Tantangan". MIIPS, 7(2).

Sofyan, Ayi., \& Marjani, GI. (2016). Implementasi Kebijakan Pencegahan Radikal Terorisme di Provinsi Jawa Barat. Bandung : Tim riset UIN SGD Bandung

US Army TRADOC, (2007), Military Guide to Terrorism, US TRADOC, Kansas, hlm II-5, URL fas.org/irp/threat/terrorism/guide.pdf, diakses tanggal 10 Maret 2017.

Utawijaya, K. (2019). Focus Group Discussion (Diskusi Kelompok Terfokus) sebagai Metode Pengum18pulan Data Kualitatif. Bandung

Wijaya, I.. (2013). "Jawa Barat Paling Rawan Terorisme". [online] tempo.co. Available at https://nasional.tempo.co/read/51070 1/jawa-barat-paling-rawanterorismelfull\&view $=o k$ [Accessed 11 May 2018] 